Short Communication

\title{
Investigation of $\mathrm{Pt} / \mathrm{SnO}_{2} / \mathrm{C}$ Catalyst for Dimethyl Ether Oxidation in DDFC
}

\author{
Lehong Xing ${ }^{1,2, *}$, Yixin Wang ${ }^{1}$, Chao Sui ${ }^{1}$, Na Zhang ${ }^{2}$ \\ ${ }^{1}$ College of Chemistry and Chemical Engineering, Mu Danjiang Normal University, Mu Danjiang \\ 157012 ,China \\ ${ }^{2}$ School of Chemical Engineering and Technology, Harbin Institute of Technology, No. 92, West Da- \\ Zhi Street, Harbin 150001 China \\ *E-mail: xinglehonghit@,126.com
}

doi: $10.20964 / 2020.03 .26$

Received: 6 November 2019 / Accepted: 18 December 2019 / Published: 10 February 2020

The performance of $\mathrm{Pt}$ loading on $\mathrm{SnO}_{2} / \mathrm{C}$ support catalyst has been investigated for dimethyl ether (DME) oxidation in direct dimethyl ether fuel cells (DDFCs). The transmission electron micrograph (TEM) tests show that the sizes of Pt particles loading on different supports $\left(\mathrm{SnO}_{2} / \mathrm{C}\right.$ and $\mathrm{XC}-72$ carbon black) are nearly the same $(3.2 \mathrm{~nm})$. The cyclic voltammograms results reveal that $\mathrm{Pt} / \mathrm{SnO}_{2} / \mathrm{C}$ shows higher activity towards DME oxidation. DME prefers to be adsorbed on $\mathrm{Pt} / \mathrm{SnO}_{2} / \mathrm{C}$ surface. $\mathrm{SnO}_{2}$ can adsorb $\mathrm{OH}_{\text {ads }}$ species which benefit to reduce the Pt poisoning effect. The maximum power density of DDFC has been enhanced by using $\mathrm{Pt} / \mathrm{SnO}_{2} / \mathrm{C}$ as the anodic catalyst. The electrochemical active surfaces $(E A S)$ of different anodes are nearly the same. That is, the improvement of DDFC performance can be attributed to the enhanced activity of anode catalyst.

Keywords: Direct dimethyl ether fuel cell; Dimethyl ether; Anode catalyst; Supports; $\mathrm{Pt} / \mathrm{SnO}_{2} / \mathrm{C}$

\section{$\underline{\text { FULL TEXT }}$}

(C) 2020 The Authors. Published by ESG (www.electrochemsci.org). This article is an open access article distributed under the terms and conditions of the Creative Commons Attribution license (http://creativecommons.org/licenses/by/4.0/). 